Final Report

FHWA/IN/JTRP-2006/18

\title{
EVALUATION OF WILDLIFE REFLECTORS IN REDUCING VEHICLE-DEER COLLISIONS ON INDIANA INTERSTATE 80/90
}

\author{
By \\ Sedat Gulen \\ Statistical Pavement Research Engineer \\ Division of Research \\ P.O. Box 2279, West Lafayette, IN 47906 \\ Phone: (765) 463-1521 \\ Fax: (765) 497-1665 \\ E-mail: sedatg@highstream.net \\ George McCabe \\ Professor \\ Department of Statistics \\ Purdue University \\ West Lafayette, IN 47906 \\ Ira Rosenthal \\ Professor \\ Palm Beach Community College \\ Palm Beach Gardens, FL 33405 \\ Samuel E. Wolfe \\ Indiana Department of Transportation \\ Toll Road Division \\ 52551 Ash Road \\ P.O. Box 1 \\ Granger, IN 46530-001 \\ Virgil. L. Anderson \\ Prof. Emeritus \\ Purdue University \\ West Lafayette, IN 47906 \\ Joint Transportation Research Program \\ Project Number: C-36-59BBB \\ File Number: 8-5-54 \\ SPR-2449 \\ Prepared in Cooperation with the \\ Indiana Department of Transportation and the \\ U. S. Department of Transportation \\ Federal Highway Administration
}

The contents of this report reflect the views of the authors, who are responsible for the facts and the accuracy of the data presented herein. The contents do not necessarily reflect the official views and policies pf the Indiana Department of Transportation or Federal Highway Administration at the time of publication. The report does not constitute a standard, specification or regulation.

Purdue University

West Lafayette, IN 47907

July 2006 


\section{TECHNICAL Summary}

INDOT Research

Technology Transfer and Project Implementation Information

TRB Subject Code: 51 Transportation Safety

Publication No.FHWA/IN/JTRP-2006/18, SPR-2449

July 2006

Final Report

\section{Evaluation of Wildlife Reflectors in Reducing Vehicle-Deer Collisions on Indiana Interstate 80/90}

\section{Introduction}

The Indiana Department of Transportation (INDOT) Operations Division is committed to reducing vehicle-deer collision incidents on the Indiana Interstate 80/90. Very few of the studies to reduce vehicle-deer collisions incorporated any sound statistical design. Some states (California, Colorado, Maine, Washington State, and Wyoming) have found that the use of wildlife reflectors did not reduce vehicle-deer collisions. However, some other states (Iowa, Minnesota, Oregon, and Wisconsin) and British Columbia-Canada found that the use of wildlife reflectors did reduce vehicle-deer collisions. INDOT is interested in cost-effective use of the StrieterLite Reflectors to reduce vehicle-deer collision incidents on the Interstate 80/90.

\section{Findings}

The following conclusions and recommendations were made on the basis of this study:

1. The effects of the reflector color, reflector spacing, median with or without reflectors, single or double reflectors and their interactions are not statistically significant.

2. The effects of the previous year data, 1998, number of deer-kills, are not statistically significant.

\section{Implementation}

The cost-effectiveness of the reduction in deer vehicle collisions due to the use of reflectors
3. When comparing all combined reflector sites with all combined control sites, the Poisson Regression Analyses indicate that the difference between the Poisson Mean $(\mu)$ of the all reflectors sections and all the control sections is statistically significant. The use of reflectors provides an expected reduction in deer-vehicle collisions of 19\% with 95\% confidence limits of $5 \%$ to $30 \%$. Maximum reduction is associated with $100 \mathrm{ft}$ spacing regardless of the reflector color, median with or without reflectors, single or double reflectors.

\section{Contacts}


For more information:

Dr. Samy Noureldin

Mr. Sedat Gulen

Indiana Department of Transportation

Office of Research and Development

1205 Montgomery Road

P.O. Box 2279

West Lafayette, IN 47906

Phone: (765) 463-1521

Fax: (765) 497-1665
1205 Montgomery Street

P.O. Box 2279

West Lafayette, IN 47906

Phone: (765) 463-1521

Fax: (765) 497-1665

Purdue University

Joint Transportation Research Program

School of Civil Engineering

West Lafayette, IN 47907-1284

Phone: (765) 494-9310

Fax: (765) 496-7996

E-mail: jtrp@ecn.purdue.edu

http://www.purdue.edu/jtrp

Indiana Department of Transportation

Office of Research and Development 


\section{ACKNOWLEDGMENTS}

This report was prepared by Sedat Gulen, George McCabe, Samuel E. Wolfe and Ira Rosenthal, for the Indiana Department of Transportation, Toll Road Division. The authors wish to thank Bob of Tollroad who maintained the reflectors, Larry Bateman, David Hinshaw and Samy Noureldin for their time and inputs. 


\section{Introduction:}

The Indiana Department of Transportation Operation Division is committed to reducing vehicle-deer collision incidents on the Indiana Interstate I-80/90. Very few of the studies to reduce vehicle-deer collisions incorporated any sound statistical design. Some states $^{(1)}$ (California, Colorado, Maine, Ontario-Canada, Washington State and Wyoming) have found that the use of wildlife reflectors did not reduce vehicle-deer collisions. However, some other states ${ }^{(2)}$ (British Columbia-Canada, Iowa, Minnesota, Oregon, Washington State and Wisconsin) found that the use of wildlife reflectors did reduce vehicle-deer collisions. INDOT is interested in cost-effective use of the Strieter-Lite Reflectors to reduce vehicle-deer collision incidents on the Interstate I-80/90.

\section{Objective:}

The main objective of this study is to evaluate the Strieter-Lite Reflectors to reduce the vehicle-deer collisions on the Indiana Interstate I-80/90.

\section{Experimental Design:}

The experimental design ${ }^{(3)}$ of this research study in detail is as follows:

(a) Reflector colors, fixed, two levels

1. Red

2. Blue/Green

(b) Reflector Spacing, fixed, two levels

1. $30 \mathrm{~m}(\sim 100$ feet $)$

2. $45 \mathrm{~m}(\sim 150$ feet $)$

(c) Reflector Design, fixed, two levels

1. Single Reflector

2. Dual Reflector 
(d) Median, fixed, two levels

1. Median with reflector

2. Median without reflector

\section{(e) Replicates, random, two levels}

The above design yields eight treatment combinations for each color, T1 to T8, Table 1. The whole experiment is called as a replicate that consists of sixteen treatment combinations, eight combinations for each color. This replicate was repeated two times. The replicates were randomly assigned to geographically homogenous portion of the Interstate and four-mile long spacing was maintained in between.

\section{(f) Control Sections, fixed, three levels}

1. Two miles long, before the first replicate

2. Four miles long, between the two replicates

3. Two miles long, after the second replicate.

Monthly data (number of deer-vehicle collisions) have been obtained at each mile including the three control sections since March 1999. 


\section{Site Selection and Reflector Installation}

Test sites for two replicates were selected randomly with four miles of control sections between the two replicates. The control area between replicates has no reflectors. Reflectors were installed uniformly with respect to the design of experiment.

Treatment combinations were randomized for each replicate. The starting color of the reflector was also randomized. The final layout of the experiment is shown in Tables 2 and 3. The length of each treatment and control section is one mile. Placements of the reflectors for different conditions are shown in Figures 1-4. All the reflectors were installed in accordance with the manufacturer's suggestions. Typical single and double reflector is seen in Figure 5. Installation of all reflectors was completed by February 1999.

\section{Data Collection:}

The daily number of deer-vehicle collision data collection was started in March 1999 and continued to the end of 2005. The reflectors have been examined, cleaned, repaired or replaced when necessary. The uniformity of the reflectors was very important for the statistical analyses, for this reason, they were maintained during this experimental study. 


\section{Data Analysis:}

Five years of deer-vehicle incidents per mile have been collected prior to the placement of the wild life reflectors and 1998 data was selected to be used as a covariate in the statistical analyses.

The new collected and past data indicated that the most deer-vehicle incidents occur during the months of April, May, October and November, (Figure 6). The following are possible reasons:

1. In the first "smaller peak" (April-May) accidents are higher because of fawning. The increased nutritional requirements of raising young cause females to move and feed more often. In addition, the landscape begins to change with the "green-up" of vegetation and subsequent introduction of higher quality food.

2. In the "larger peak" (October-November) several things are occurring:

a. Males and females are both undergoing behavioral changes induced by the rut (breeding season). The animals are not only more active, but also more brazen and careless.

b. The landscape is changing drastically. Crops are harvested and understory growth dies off as leaves fall. This reduces cover and food availability for deer necessitating greater travel.

c. Hunting season, particularly the end of archery and the firearms season (mid November) sees several hundred thousand hunters take to the field, which causes extensive movement of animals.

For the above stated reasons data from the peak months, i.e. April, May, October and November, were analyzed.

Poisson regression models were found to be suitable for the analysis since the values of the dependent variable, the number of deer-kills, are non-negative integers. 


\section{Poisson Regression Model}

The Poisson regression model gets its name from the assumption that the dependent variable has a Poisson distribution, defined as follows. Let $\mathbf{y}$ be a variable that can only have non-negative integer values. We assume that the probability that $\mathbf{y}$ is equal to some number $\mathbf{r}$ is given by

$$
\operatorname{Pr}(y=r)=\frac{\mu^{r} e^{-\mu}}{r !} \quad \mathbf{r}=0,1,2 \ldots
$$

where $\mu$ is the expected value (mean) of $\mathbf{y}$ and $\mathbf{r} !=\mathbf{r}(\mathbf{r}-\mathbf{1})(\mathbf{r}-\mathbf{2}) \ldots(\mathbf{1})$. Although $\mathbf{y}$ can only take on integer value, $\mu$ can be any positive number.

As $\mu$ gets larger, the Poisson distribution can be approximated by a normal distribution. For the Poisson distribution the mean and the variance are equal.

$$
\text { Expected value of } \mathbf{y}=\mathbf{E}(\mathbf{y})=\text { variance }(y)=\mu
$$

For a Poisson regression model, the parameter $\mu$ depends on the explanatory variables. First, we write $\mu_{\mathbf{i}}$ with a subscript $\mathbf{i}$ to allow parameter to vary across conditions $(i=1,2 \ldots$ n). The standard model expresses $\mu$ as a loglinear function of the explanatory (x) variables:

$$
\log \mu_{\mathrm{i}}=\beta_{0}+\beta_{1} \mathbf{x}_{\mathrm{i} 1}+\beta_{2} \mathbf{x}_{\mathrm{i} 2}+\ldots+\beta_{\mathrm{p}} \mathbf{x}_{\mathrm{ip}}
$$

This relationship will make $\mu$ greater than zero for any values of the $\mathbf{x}$ 's or $\beta$ 's. We choose the maximum likelihood method to estimate the parameters of the model, the $\beta$ 's. This is easily accomplished using the $\mathrm{SAS}^{(6)}$ Statistical Software with "PROC GENMOD” version 8.0.

When using the Poisson regression modeling, one should be aware of "overdispersion". When count variables often have a variance greater than the mean, this is called overdispersion. Overdispersion can occur when there are explanatory variables that are omitted from the model, (Overdispersion can lead to underestimates of the standard errors and overestimates of chi-square statistics. 
What can be done about overdispersion? One can use the Pearson chi-square or the deviance chi-square correction in the model. These two methods are very close, however, the theory of quasi-likelihood estimation suggest the use of the Pearson chi-square (McCullagh and Nelder 1989) ${ }^{(4)}$.

The adjustment for overdispersion discussed above is a huge improvement over conventional Poisson regression but it may not be ideal. The coefficients are still inefficient, meaning that they have more sampling variability than necessary. Efficient estimates are produced by an alternative model called negative binomial regression.

The negative binomial model is a generalized of the Poisson model. We modify equation (3) by adding a disturbance term, which accounts for the overdispersion:

$$
\log \mu_{\mathrm{I}}=\beta_{0}+\beta_{1} \mathrm{x}_{\mathrm{i} 1}+\beta_{2} \mathrm{x}_{\mathrm{i} 2}+\ldots+\beta_{\mathrm{p}} \mathrm{x}_{\mathrm{ip}}+\sigma \varepsilon_{\mathrm{i}}
$$

We assume that the dependent variable $\mathbf{y}_{\mathbf{i}}$ has a Poisson distribution with expected value $\mu_{\mathrm{i}}$, conditional on $\varepsilon_{\mathrm{i}}$. Finally, we assume that expected $\left(\varepsilon_{\mathrm{i}}\right)$ has a standard gamma distribution (Agresti 1990, page 74) ${ }^{(5)}$. Then, it follows that the unconditional distribution of $\mathbf{y}_{\mathbf{i}}$ is negative binomial distribution. The negative binomial regression model may be efficiently estimated by maximum likelihood. This is also easily accomplished using the SAS Statistical Software with "PROC GENMOD" version 8.0.

The Poisson regression model with the Pearson chi-square and the negative binomial regression were used for the analysis of our data. 


\section{Main Experiment:}

This experiment is called completely randomized ${ }^{(3)}$. The main purpose of the analysis is to assess the effects of the main effects, replicate, rate, month, color, reflector type, and reflector spacing, median and all the two-way interactions of color, reflector type, reflector spacing and median. Then the following model was used:

$\log \left(\mu_{\mathrm{i}}\right)=\beta_{0}+\beta_{1}$ REP (1) $+\beta_{2}$ MONTH (4) $+\beta_{3}$ MONTH (5) $+\beta_{4}$ MONTH (10) + $\beta_{5}$ MONTH (11) $+\beta_{6}$ MONTH (16) $+\ldots \ldots \ldots \ldots$

$$
\begin{aligned}
& \theta_{1} \operatorname{COLOR}(1)+\theta_{2} \operatorname{SPACE}(1)+\theta_{3} \operatorname{REF}(1)+\theta_{4} \operatorname{MEDIAN}(1)+ \\
& \theta_{5} \operatorname{COLOR}(1) * \operatorname{SPACE}(1)+\theta_{6} \operatorname{COLOR}(1) * \operatorname{REF}(1)+ \\
& \theta_{7} \operatorname{COLOR}(1) * \operatorname{MEDIAN}(1)+\theta_{8} \operatorname{SPACE}(1) * \operatorname{REF}(1)+ \\
& \theta_{9} \operatorname{SPACE}(1) * \operatorname{MEDIAN}(1)+\theta_{10} \operatorname{REF}(1) * \operatorname{MEDIAN}(1)+\gamma \mathrm{X}_{\mathrm{i}}
\end{aligned}
$$

Where:

$\mu_{\mathrm{i}}=\mathrm{E}(\mathrm{y})$, the mean of the $\mathrm{i}$-th observation

REP $(1)=$ effect of the replicate $=(1$ if replicate $=1,0$ otherwise $)$

MONTH (4) $=$ effect of the month $=(1$ if month=4, 0 otherwise $)$

MONTH $(5)=$ effect of the month $=(1$ if month=5, 0 otherwise $)$

MONTH $(10)=$ effect of the month $=(1$ if $\operatorname{month}=10,0$ otherwise $)$

MONTH $(11)=$ effect of the month $=(1$ if month=11, 0 otherwise $)$

MONTH $(16)=$ effect of the month $=(1$ if month=16, 0 otherwise $)($ April in 2000)

MONTH $(17)=$ effect of the month $=(1$ if month=17, 0 otherwise $)($ May in 2000 $)$

COLOR $(1)=$ effect of the color $=(1$ if color is red, 0 otherwise $)$

SPACE $(1)=$ effect of the reflector spacing $=(1$ if spacing is $30 \mathrm{~m}, 0$ otherwise $)$

REF $(1)=$ effect of the reflector type $=(1$ if reflector is single, 0 otherwise $)$

MEDIAN $(1)=$ effect of the median $=(1$ if median is without reflector, 0 otherwise $)$ $X_{i}=$ the covariate, the number of vehicle-deer collisions occurred in 1998. 
COLOR (1)*SPACE (1) = interaction of the Color with Space.

COLOR (1)*REF (1) = interaction of the color with reflector type.

REF (1)*MEDIAN (1) = interaction of the reflector type with median.

The corresponding indicator variables were generated for all the terms in equation (6) except the covariate $\mathrm{X}$. This is accomplished by the SAS software by including the explanatory variables in a CLASS statement. The Poisson and negative binomial regressions models were used for the analysis. Results are listed in Tables 5 and 6.

Both methods indicated that the effects of the following terms are not statistically significant:

1. The effect of the covariate, $\mathrm{X}$, the numbers of deer-kills in 1998 , $\mathrm{p}$-value $=0.23$ for Poisson and $\mathrm{p}$-value $=0.23$ from negative binomial.

2. The effect of the replicate, $p$-value $=0.49$ and 0.49 from Poisson and Negative-Binomial.

3. The effects of color, spacing, reflector and median

4. The two-way interactions of the color, spacing, reflector and median

The only term, which is statistically significant, is the months as expected. 


\section{Comparisons of treatments with controls:}

These comparisons were made in the following two ways:

\section{A. Individual comparisons of the treatments:}

Each of the sixteen reflector treatments was individually compared with each of the controls. The treatments are shown as TRT in Table 3 . The reflector treatments are numbered from 1 to 16 in each replicate and the controls are numbered from 17 to 20 . The following model was used:

$$
\begin{aligned}
\log \left(\mu_{\mathrm{i}}\right)= & \beta_{0}+\beta_{1} \operatorname{REP}(1)+\beta_{2} \operatorname{MONTH}(4)+\beta_{3} \operatorname{MONTH}(5)+\beta_{4} \operatorname{MONTH}(10)+ \\
& \beta_{5} \operatorname{MONTH}(11)+\beta_{6} \operatorname{MONTH}(16)+\ldots \ldots \ldots \ldots \\
& \phi_{1} \operatorname{TRT}(1)+\phi_{2} \operatorname{TRT}(2)+\phi_{3} \operatorname{TRT}(3)+\phi_{4} \operatorname{TRT}(4)+\phi_{5} \operatorname{TRT}(5)+ \\
& \phi_{6} \operatorname{TRT}(6)+\phi_{7} \operatorname{TRT}(7)+\phi_{8} \operatorname{TRT}(8)+\phi_{9} \operatorname{TRT}(9)+\phi_{10} \operatorname{TRT}(10)+\phi_{11} \operatorname{TRT}(11)+ \\
& \phi_{12} \operatorname{TRT}(12)+\phi_{13} \operatorname{TRT}(13)+\phi_{14} \operatorname{TRT}(14)+\phi_{15} \operatorname{TRT}(15)+ \\
& \phi_{16} \operatorname{TRT}(16)+\phi_{17} \operatorname{TRT}(17)+\phi_{18} \operatorname{TRT}(18)+\phi_{19} \operatorname{TRT}(19)+\phi_{20} \operatorname{TRT}(20) \\
& \gamma \mathrm{X}_{\mathrm{i}} \ldots \ldots \ldots
\end{aligned}
$$

where:

TRT $(1)=$ effect of the treatment $=(1$ if TRT $=1,0$ otherwise $)$

TRT (2) $=$ effect of the treatment $=(1$ if TRT $=2,0$ otherwise $)$

TRT (3) $=$ effect of the treatment $=(1$ if TRT $=3,0$ otherwise $)$

TRT $(19)=$ effect of the treatment $=(1$ if TRT $=19,0$ otherwise $)$

The other terms are defined before. 
The Poisson Regression analysis using the model, equation (6) showed that the following terms are not statistically significant (Table 7):

1. The covariate, $\mathrm{X}, \mathrm{p}$-value $=0.12$

2. $\quad$ TRT, $p$-value $=0.59$

3. $R E P, p-v a l u e=0.63$

The only significant term is month as found before. The p-value of 0.59 for the TRT, indicates that differences among the 20 treatments (16 with reflectors and four controls) are not statistically significant.

Even though the treatments (TRT) failed to be statistically significant, comparisons of the controls $(\operatorname{trt}=17,18,19$ and 20$)$ with the other treatments $(\operatorname{trt}=1,2 \ldots 16)$ were checked. These comparisons also failed to attain statistically significance (Table 8). The p-values are greater than 0.10 .

For Example:

a) The $p$-value for the difference between the TRT=4 and TRT $=20$ (one of the four controls) is 0.1009 , Table 8 .

b) The $p$-value for the difference between the TRT=15 and TRT=19 (one of the four controls) is 0.9656 , Table 8 . 


\section{B. Comparisons of all reflector treatments to the controls:}

There are four controls, designated as $\operatorname{trt}=17,18,19$ and 20 in two replicates (rep). They are named as group 17, 18, 19 and 20.

The 16 reflector treatments are included in group 1.

The following Poisson Regression Model (7) was used to analyze the data.

$$
\begin{aligned}
\log \left(\mu_{\mathrm{i}}\right)= & \beta_{0}+\beta_{1} \operatorname{REP}(1)+\beta_{2} \operatorname{MONTH}(4)+\beta_{3} \operatorname{MONTH}(5)+ \\
& \beta_{4} \operatorname{MONTH}(10)+\beta_{5} \operatorname{MONTH}(11)+\beta_{6} \operatorname{MONTH}(16)+\ldots \ldots \ldots \\
& \phi_{1} \operatorname{GROUP}(1)+\phi_{2} \operatorname{GROUP}(17)+\phi_{3} \operatorname{GROUP}(18)+ \\
& \phi_{4} \operatorname{GROUP}(19)+\phi_{5} \operatorname{GROUP}(20) \\
& +\gamma \mathrm{X}_{\mathrm{i}} \quad \ldots \ldots \ldots . .(7)
\end{aligned}
$$

The results, as tabulated in Table 9, show that the following variables are not statistically significant:

1) REP, $p$-value $=0.62$

2) Covariate, $X, p$-value $=0.11$

3) GROUP, $\mathrm{p}$-value $=0.06$

The explanatory variable, month was found statistically significant as expected.

The term Group was not statistically significant, $p$-value $=0.06$ and this again indicates that the differences among controls and reflectors are not evident in these data.

In addition, the differences between groups were also obtained and it shows that the only significant difference is between GROUP (1) that includes all reflectors and the GROUP (20) that includes the two control sections designated as $\operatorname{trt}=20$. 


\section{Comparisons of all reflectors treatments with all controls}

The reflectors treatments, $\operatorname{trt}=1,2,3 \ldots .16$ in two replicates are designated as COM 1 while all the controls, trt=17, 18, 19 and 20 were designated as COM 2. In other words, COM 1 includes all the reflectors treatments when COM 2 includes all the controls.

The following Poisson Regression Model (8) was used to analyze the data. $\log \left(\mu_{\mathrm{i}}\right)=\beta_{0}+\beta_{1}$ REP (1) $+\beta_{2}$ MONTH (4) $+\beta_{3}$ MONTH (5) + $\beta_{4} \operatorname{MONTH}(10)+\beta_{5} \operatorname{MONTH}(11)+\beta_{6} \operatorname{MONTH}(16)+\ldots \ldots \ldots$ $\phi_{1} \mathrm{COM}+\gamma \mathrm{X}_{\mathrm{i}}$

The results of Poisson model tabulated in Table 10 indicate that the difference between the Poisson Mean $(\mu)$ of the all reflectors and all the control is statistically significant, $p$-value $=0.01$. This may be due to the control section $20(\operatorname{trt}=20)$ which is two miles away from each replicate of reflectors on the right side.

Table 11 shows the estimate and the 95 percent confidence interval COM 1. The estimate is -0.20 and the confidence interval is

$$
(-0.36 \text { to }-.05)
$$

These values can be translated to expected reductions in vehicle-deer collisions due to reflectors: 1 - e- $0.36=0.30,1-\mathrm{e}-0.05=0.05$ and $1-\mathrm{e} 0.20$ $=0.19$. The expected reduction is $19 \%$ with $95 \%$ confidence limits of $5 \%$ to $30 \%$. 


\section{CONCLUSIONS}

The following conclusions were based on the experimental research study:

1. The effects of the reflector color, reflector spacing, median with or without reflectors, single or double reflectors and their interactions are not statistically significant.

2. The effects of the previous year data, 1998, number of deer-kills, are not statistically significant

3. When comparing all combined reflector sites with all combined control sites, the Poisson Regression Analyses indicate that the difference between the Poisson Mean $(\mu)$ of the all reflectors sections and all the control sections is statistically significant. The use of reflectors provides an expected reduction in deer-vehicle collisions of $19 \%$ with $95 \%$ confidence limits of 5\% to $30 \%$. Maximum reduction is associated with $100 \mathrm{ft}$ spacing regardless of the reflector color, median with or without reflectors, single or double reflectors.

4. Cost effectiveness of the reduction described above will be behind any decision to use reflectors to reduce vehicle-deer collisions. 


\section{REFERENCES}

(1) Roadside Wildlife Reflectors-Do They Work? Road Management Journal, May 12, 1997, TranSafety, Inc.

(2) Swareflex Wildlife Warning Reflectors: One Preventive Measure for Wildlife-Vehicle Collisions, Road Management Journal, August 11, 1997, TranSafety, Inc.

(3) Design of Experiments- A Realistic Approach, by Virgil L. Anderson and Robert A. McLean, 1974, Marcel Dekker, Inc.

(4) Categorical Data Analysis, by Agresti, A. (1990): John Wiley \& Sons.

(5) Generalized Linear Models, by McCullagh, P. and Nelder, J. A. Second edition. London: Chapman and Hall.

(6) SAS/STAT Software, Version 8. SAS Institute Inc. SAS Campus Drive, Cary, NC 2 


\section{LIST OF TABLES}

$\underline{\text { Tables }}$

Table 1

Table 2

Table 3

Table 4

Table 5

Table 6

Table 7

Table 8

Table 9

Table 10

Table 11

\section{Descriptions}

Design of Experiment for each reflector color

Final layout of the experiment

Treatments

Treatments Combinations

Poisson Distribution Outputs

Negative-Binomial Distribution Outputs

Differences between treatments and controls

Differences between treatments and controls

Differences between Treatments Combinations

And Controls

Comparisons of all reflectors to all controls

95\% Wald Confidence Interval of the variables
29

Page

20

21

22

23

24

25

26

27

30

31 


\section{LIST OF FIGURES}

Figures

Figure 1

Figure 2

Figure 3

Figure 4

Figure 5

Figure 6

Figure 7

\section{Descriptions}

Typical Installation of reflectors (T3 and T7)

Typical Installation of reflectors (T4 and T8)

Typical Installation of reflectors (T1 and T5)

Typical Installation of reflectors (T2 and T6)

Single and double reflector

The number of deer-kills along the test sections

The number of deer killed along the mile posts
Page

32

33

34

35
36

37

38 
Table 1.

Design of Experiment

For each reflector color

\begin{tabular}{|c|c|c|c|c|c|c|c|}
\hline \multicolumn{8}{|c|}{ SPACING OF REFLECTORS } \\
\hline \multicolumn{4}{|c|}{$30 \mathrm{~m}$ (100 feet) } & \multicolumn{4}{|c|}{45 m (150 feet) } \\
\hline \multicolumn{4}{|c|}{ SHOULDER REFLECTOR DESIGN } & \multicolumn{4}{|c|}{ SHOULDER REFLECTOR DESIGN } \\
\hline \multicolumn{2}{|c|}{ SINGLE REFLECTOR } & \multicolumn{2}{|c|}{ DUAL REFLECTOR } & \multicolumn{2}{|c|}{ SINGLE REFLECTOR } & \multicolumn{2}{|c|}{ DUAL REFLECTOR } \\
\hline \multicolumn{2}{|c|}{ MEDIAN } & \multicolumn{2}{|c|}{ MEDIAN } & \multicolumn{2}{|c|}{ MEDIAN } & \multicolumn{2}{|c|}{ MEDIAN } \\
\hline $\begin{array}{c}\text { WITH } \\
\text { REFLECTOR } \\
\end{array}$ & $\begin{array}{c}\text { WITHOUT } \\
\text { REFLECTOR } \\
\end{array}$ & $\begin{array}{c}\text { WITH } \\
\text { REFLECTOR } \\
\end{array}$ & $\begin{array}{c}\text { WITHOUT } \\
\text { REFLECTOR }\end{array}$ & $\begin{array}{c}\text { WITH } \\
\text { REFLECTOR } \\
\end{array}$ & $\begin{array}{c}\text { WITHOUT } \\
\text { REFLECTOR } \\
\end{array}$ & $\begin{array}{c}\text { WITH } \\
\text { REFLECTOR } \\
\end{array}$ & $\begin{array}{c}\text { WITHOUT } \\
\text { REFLECTOR }\end{array}$ \\
\hline T1 & T2 & T3 & T4 & T5 & T6 & $\mathrm{T} 7$ & T8 \\
\hline
\end{tabular}

T1, T2...T8 are the treatment combinations. 
Table 2.

The final layout of the Experiment

\begin{tabular}{|c|c|c|c|c|c|c|c|c|c|c|c|c|c|c|c|c|c|c|c|c|c|c|c|}
\hline \multicolumn{4}{|c|}{$\begin{array}{l}\text { Control } \\
\text { Sections }\end{array}$} & \multicolumn{16}{|c|}{ Replicate 1} & \multicolumn{4}{|c|}{$\begin{array}{l}\text { Control } \\
\text { Sections }\end{array}$} \\
\hline 4 & 3 & 2 & 1 & T5 & & T8 & & T3 & & $\mathrm{T} 1$ & & $\mathrm{~T} 7$ & & $\mathrm{~T} 2$ & & T6 & & $\mathrm{T} 4$ & & 1 & 2 & 3 & 4 \\
\hline \multicolumn{4}{|c|}{ Mile Posts } & & $\underline{\mathrm{T} 7}$ & & T3 & & $\mathbf{T 1}$ & & $\underline{T 6}$ & & $\underline{\mathrm{T}} 4$ & & $\mathrm{T8}$ & & $\mathrm{T} 2$ & & $\underline{\mathrm{T} 5}$ & \multirow{2}{*}{\multicolumn{4}{|c|}{\begin{tabular}{|c|} 
Mile Posts \\
\end{tabular}}} \\
\hline 82 & 83 & 84 & 85 & 86 & $\overline{87}$ & 88 & 89 & 90 & $\overline{91}$ & 92 & $\overline{93}$ & 94 & 95 & 96 & $\overline{97}$ & 98 & $\overline{99}$ & 100 & $\overline{101}$ & 102 & & & 106 \\
\hline
\end{tabular}

\begin{tabular}{|c|c|c|c|c|c|c|c|c|c|c|c|c|c|c|c|c|c|c|c|}
\hline \multicolumn{16}{|c|}{ Replicate 2} & \multicolumn{4}{|c|}{ Control Sections } \\
\hline T3 & & T7 & & T5 & & T1 & & T4 & & T6 & & T8 & & T2 & & 1 & 2 & 3 & 4 \\
\hline & $\underline{\mathrm{T} 8}$ & & $\underline{T 1}$ & & $\underline{\mathrm{T} 3}$ & & $\underline{T 6}$ & & T2 & & $\underline{\mathrm{T7}}$ & & T4 & & $\underline{T 5}$ & \multicolumn{4}{|c|}{ Mile Posts } \\
\hline 107 & $\overline{108}$ & 109 & 110 & 111 & 112 & 113 & 114 & 115 & 116 & 117 & 118 & 119 & 120 & 121 & 122 & 123 & 124 & 125 & 126 \\
\hline
\end{tabular}

Note: $\mathrm{T} 1, \mathrm{~T} 2, \mathrm{~T} 8$ are the treatments in red colors while $\underline{\mathrm{T} 1}, \underline{\mathrm{T} 2}, \ldots \underline{\mathrm{T} 8}$ are the treatment combinations in Blue/Green colors. 
Table 3. Treatments versus Controls

\begin{tabular}{|c|c|c|c|c|c|c|c|c|c|c|c|c|c|c|c|c|c|}
\hline \multicolumn{3}{|c|}{ CONTROLS } & \multicolumn{3}{|c|}{ REPLICATE=1 } & \multicolumn{5}{|c|}{ CONTROLS } & \multicolumn{4}{|c|}{ REPLICATE=2 } & \multicolumn{3}{|c|}{ CONTROLS } \\
\hline TRT & 17 & 18 & & $1234 \ldots . .1$ & & 19 & 20 & & 17 & 18 & & $123 \ldots$. & & & 19 & 20 & TRT \\
\hline $\begin{array}{l}\text { Miles } \\
\text { Post }\end{array}$ & 84 & 85 & 86 & ................... & 101 & 102 & 103 & 104 & 105 & 106 & 107 & ……............... & 121 & 122 & 123 & 124 & $\begin{array}{c}\text { Mile } \\
\text { Posts }\end{array}$ \\
\hline
\end{tabular}


Table 4. Treatment Combinations

\begin{tabular}{|c|c|c|}
\hline \multirow{3}{*}{$\begin{array}{c}\text { SPACE } \\
30 \mathrm{~m}\end{array}$} & \multicolumn{2}{|c|}{ COLOR (S1) } \\
\hline & RED & BLUE/GREEN \\
\hline & trt1 trt2 trt3 trt4 $\mathbf{S}=\mathbf{1}$ & trt9 $\operatorname{trt10} \operatorname{trt11} \operatorname{trt12} \mathbf{S}=3$ \\
\hline $45 \mathrm{~m}$ & trt5 trt6 trt7 trt8 $\mathbf{S}=\mathbf{2}$ & Trt13 trt14 trt15 trt16 $\mathbf{S = 4}$ \\
\hline
\end{tabular}

\begin{tabular}{|c|c|c|}
\hline \multirow[t]{2}{*}{ REFLECTOR } & \multicolumn{2}{|c|}{ COLOR (S2) } \\
\hline & RED & BLUE/GREEN \\
\hline SINGLE & trt1 trt2 trt5 trt6 $\mathbf{S}=\mathbf{1}$ & trt9 $\operatorname{trt10}$ trt13 $\operatorname{trt14} \quad \mathbf{S}=3$ \\
\hline DOUBLE & Trt3 trt4 trt7 trt8 $\mathbf{S}=\mathbf{2}$ & Trt11 trt12 trt15 trt16 $\mathbf{S = 4}$ \\
\hline
\end{tabular}

\begin{tabular}{|c|c|c|}
\hline & \multicolumn{2}{|c|}{ COLOR (S3) } \\
\hline MEDIAN & RED & BLUE/GREEN \\
\hline WITH REFLECTOR & Trt2 trt4 trt6 trt8 $\mathbf{S = 1}$ & Trt10 trt12 trt14 trt16 $\quad S=3$ \\
\hline $\begin{array}{c}\text { WITHOUT } \\
\text { REFLECTOR }\end{array}$ & Trt1 trt3 trt5 trt7 $\mathbf{S}=\mathbf{2}$ & Trt9 trt11 trt13 trt15 $\quad \mathbf{S}=\mathbf{4}$ \\
\hline
\end{tabular}

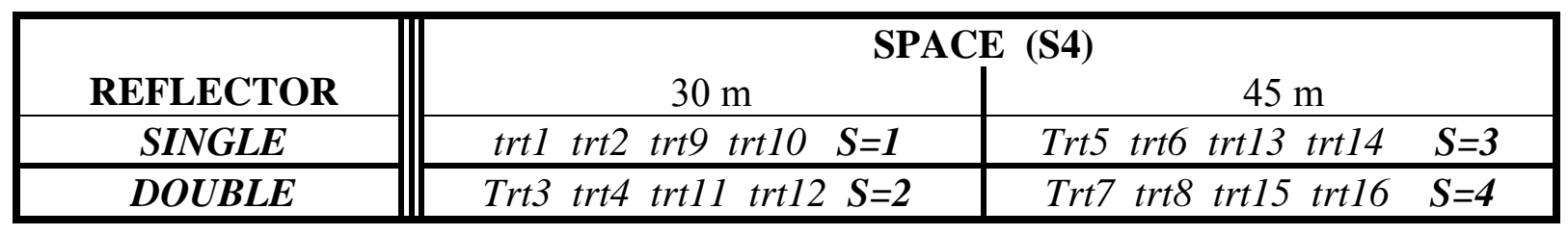

\begin{tabular}{|c|c|c|}
\hline \multirow{3}{*}{$\begin{array}{c}\text { MEDIAN } \\
\text { WITH REFLECTOR }\end{array}$} & \multicolumn{2}{|c|}{ SPACE (S5) } \\
\hline & $30 \mathrm{~m}$ & $45 \mathrm{~m}$ \\
\hline & Trt2 trt4 trt10 trt12 $\mathbf{S = 1}$ & Trt6 trt8 trt14 trt16 $\quad \mathrm{S}=3$ \\
\hline $\begin{array}{c}\text { WITHOUT } \\
\text { REFLECTOR }\end{array}$ & Trt1 trt3 trt9 trt11 $\mathbf{S = 2}$ & Trt5 trt7 trt13 trt15 $\mathbf{S = 4}$ \\
\hline
\end{tabular}

\begin{tabular}{|c|c|c|c|}
\hline \multirow{3}{*}{$\begin{array}{c}\text { MEDIAN } \\
\text { WITH REFLECTOR }\end{array}$} & \multicolumn{3}{|c|}{ REFLECTOR (S6) } \\
\hline & SINGLE & DOI & \\
\hline & Trt2 trt6 trt10 trt14 $\mathbf{S = 1}$ & Trt4 trt8 trt12 trt16 & $S=3$ \\
\hline $\begin{array}{c}\text { WITHOUT } \\
\text { REFLECTOR }\end{array}$ & Trt1 trt5 trt9 trt13 $\mathbf{S = 2}$ & Trt3 trt7 trt11 trt15 & $S=4$ \\
\hline
\end{tabular}




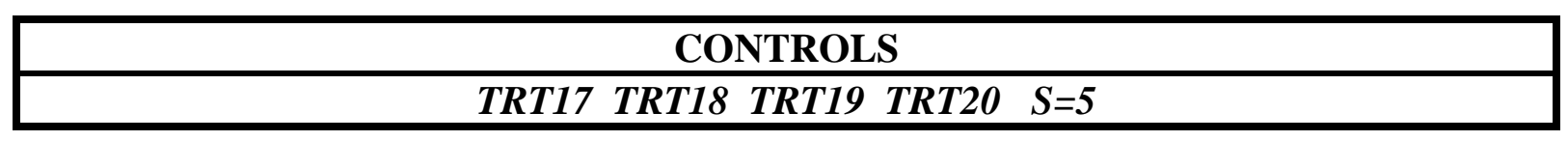

Where for example; TRT11= TRT NUMBER 11 etc. as explained in Table 3. 


\section{Table 5 \\ Using Poisson Regression Model}

\begin{tabular}{lr}
\multicolumn{2}{c}{ Model Information } \\
Data Set & WORK. NEW \\
Distribution & Poisson \\
Link Function & Log \\
Dependent Variable & y \\
Observations Used & 896
\end{tabular}

Class Level Information

\begin{tabular}{|c|c|c|}
\hline Class & Levels & Values \\
\hline month & 28 & $\begin{array}{lllllllllllllllll}5 & 6 & 10 & 11 & 17 & 18 & 22 & 23 & 29 & 30 & 34 & 35 & 41 & 42 & 46 & 47 & 53 \\
54 & 58 & 59 & 65 & 66 & 70 & 71 & 77 & 78 & 82 & 83 & & & & & & \end{array}$ \\
\hline rep & 2 & 12 \\
\hline color & 2 & 12 \\
\hline space & 2 & 12 \\
\hline ref & 2 & 12 \\
\hline median & 2 & 12 \\
\hline Rate & 4 & 1245 \\
\hline
\end{tabular}

The GENMOD Procedure

Criteria For Assessing Goodness of Fit

$\begin{array}{lrrr}\text { Criterion } & \text { DF } & \text { Value } & \text { Value/DF } \\ \text { Deviance } & 856 & 1008.8559 & 1.1786 \\ \text { Scaled Deviance } & 856 & 908.7274 & 1.0616 \\ \text { Pearson Chi-Square } & 856 & 950.3187 & 1.1102 \\ \text { Scaled Pearson X2 } & 856 & 856.000 \odot & 1.0000 \\ \text { Log Likelihood } & & -744.8256 & \end{array}$

Algorithm converged.

LR Statistics For Type 3 Analysis

\begin{tabular}{|c|c|c|c|c|c|c|}
\hline Source & Num DF & Den DF & F Value & $\mathrm{Pr}>\mathrm{F}$ & $\begin{array}{r}\text { Chi- } \\
\text { Square }\end{array}$ & $\mathrm{Pr}>\mathrm{ChiSq}$ \\
\hline rep & 1 & 856 & 0.47 & 0.4928 & 0.47 & $\odot .4926$ \\
\hline$x$ & 1 & 856 & 1.42 & 0.2333 & 1.42 & 0.2330 \\
\hline month & 27 & 856 & 3.28 & $<.0001$ & 88.61 & $<.0001$ \\
\hline color & 1 & 856 & 0.20 & $\odot .6517$ & 0.20 & 0.6516 \\
\hline space & 1 & 856 & 3.69 & $\odot .0549$ & 3.69 & 0.0546 \\
\hline ref & 1 & 856 & 0.01 & $\odot .9160$ & 0.01 & 0.9160 \\
\hline median & 1 & 856 & 0.61 & $\odot .4369$ & 0.61 & 0.4367 \\
\hline color*space & 1 & 856 & 0.60 & 0.4394 & 0.60 & 0.4391 \\
\hline color*ref & 1 & 856 & 0.75 & 0.3882 & 0.75 & 0.3880 \\
\hline color*median & 1 & 856 & 0.48 & 0.4900 & 0.48 & 0.4898 \\
\hline space*ref & 1 & 856 & 0.10 & 0.7556 & 0.10 & $\odot .7555$ \\
\hline space*median & 1 & 856 & 1.24 & 0.2657 & 1.24 & 0.2654 \\
\hline ref*median & 1 & 856 & 0.13 & 0.7144 & 0.13 & 0.7143 \\
\hline
\end{tabular}


NOTE: The scale parameter was estimated by the square root of Pearson's Chi-Square/DOF in order to eliminate if there is overdispersion. 
Table 6

Negative Binomial Distribution Criteria For Assessing Goodness of Fit

$\begin{array}{lrrr}\text { Criterion } & \text { DF } & \text { Value } & \text { Value/DF } \\ \text { Deviance } & 171 & 175.6565 & 1.0272 \\ \text { Scaled Deviance } & 171 & 175.6565 & 1.0272 \\ \text { Pearson Chi-Square } & 171 & 195.7538 & 1.1448 \\ \text { Scaled Pearson X2 } & 171 & 195.7538 & 1.1448 \\ \text { Log Likelihood } & & -156.4281 & \end{array}$

Algorithm converged.

\begin{tabular}{lr}
\multicolumn{2}{c}{ Model Information } \\
Data Set & WORK. NEW \\
Distribution & Poisson \\
Link Function & Log \\
Dependent Variable & y \\
Observations Used & 896
\end{tabular}

Class Level Information

\begin{tabular}{|c|c|c|}
\hline Class & Levels & Values \\
\hline month & 28 & $\begin{array}{lllllllllllllllll}5 & 6 & 10 & 11 & 17 & 18 & 22 & 23 & 29 & 30 & 34 & 35 & 41 & 42 & 46 & 47 & 53 \\
54 & 58 & 59 & 65 & 66 & 70 & 71 & 77 & 78 & 82 & 83\end{array}$ \\
\hline rep & 2 & 12 \\
\hline color & 2 & 12 \\
\hline space & 2 & 12 \\
\hline ref & 2 & 12 \\
\hline median & 2 & 12 \\
\hline Rate & 4 & 1245 \\
\hline
\end{tabular}

The GENMOD Procedure Criteria For Assessing Goodness of Fit

$\begin{array}{lrrr}\text { Criterion } & \text { DF } & \text { Value } & \text { Value/DF } \\ & & & \\ \text { Deviance } & 856 & 1008.8559 & 1.1786 \\ \text { Scaled Deviance } & 856 & 908.7274 & 1.0616 \\ \text { Pearson Chi-Square } & 856 & 950.3187 & 1.1102 \\ \text { Scaled Pearson X2 } & 856 & 856.0000 & 1.0000 \\ \text { Log Likelihood } & & -744.8256 & \end{array}$

Algorithm converged.

LR Statistics For Type 3 Analysis

$\begin{array}{lrrrrrr}\text { Source } & \text { Num DF } & \text { Den DF } & \text { F Value } & \text { Pr }>\text { F } & \begin{array}{c}\text { Chi- } \\ \text { Square }\end{array} & \text { Pr }>\text { ChiSq } \\ \text { rep } & 1 & 856 & 0.47 & 0.4928 & 0.47 & 0.4926 \\ \text { X } & 1 & 856 & 1.42 & 0.2333 & 1.42 & 0.2330 \\ \text { month } & 27 & 856 & 3.28 & <.0001 & 88.61 & <.0001\end{array}$




$\begin{array}{lllllll}\text { color } & 1 & 856 & 0.20 & 0.6517 & 0.20 & 0.6516 \\ \text { space } & 1 & 856 & 3.69 & 0.0549 & 3.69 & 0.0546 \\ \text { ref } & 1 & 856 & 0.01 & 0.9160 & 0.01 & 0.9160 \\ \text { median } & 1 & 856 & 0.61 & 0.4369 & 0.61 & 0.4367 \\ \text { color*space } & 1 & 856 & 0.60 & 0.4394 & 0.60 & 0.4391 \\ \text { color }^{*} \text { ref } & 1 & 856 & 0.75 & 0.3882 & 0.75 & 0.3880 \\ \text { color*median } & 1 & 856 & 0.48 & 0.4900 & 0.48 & 0.4898 \\ \text { space*ref } & 1 & 856 & 0.10 & 0.7556 & 0.10 & 0.7555 \\ \text { space*median } & 1 & 856 & 1.24 & 0.2657 & 1.24 & 0.2654 \\ \text { ref*median }^{*} & 1 & 856 & 0.13 & 0.7144 & 0.13 & 0.7143\end{array}$




\title{
Table 7. The difference between control and treatment
}

\author{
Model Information \\ Data Set \\ WORK.TTR \\ Distribution \\ Link Function \\ Dependent Variable \\ observations Used \\ Poisson \\ Log \\ $\mathrm{y}$
120 \\ Class Level Information
}

\begin{tabular}{lrllllllllllllllllllllll} 
Class & Levels & \multicolumn{1}{l}{ Values } \\
trt & 20 & 1 & 2 & 3 & 4 & 5 & 6 & 7 & 8 & 9 & 10 & 11 & 12 & 13 & 14 & 15 & 16 & 17 & 18 & 19 & 20 \\
month & 28 & 5 & 6 & 10 & 11 & 17 & 18 & 22 & 23 & 29 & 30 & 34 & 35 & 41 & 42 & 46 & 47 & 53
\end{tabular}

LR Statistics For Type 3 Analysis

$\begin{array}{lrrrrrr}\text { Source } & \text { Num DF } & \text { Den DF } & \text { F Value } & \text { Pr }>\text { F } & \begin{array}{r}\text { Chi- } \\ \text { Square }\end{array} & \operatorname{Pr}>\text { ChiSq } \\ \text { rep } & 1 & 1071 & 0.23 & 0.6295 & 0.23 & 0.6294 \\ \text { x } & 1 & 1071 & 2.43 & 0.1194 & 2.43 & 0.1191 \\ \text { month } & 27 & 1071 & 3.70 & <.0001 & 99.84 & <.0001 \\ \text { trt } & 19 & 1071 & 0.90 & 0.5847 & 17.08 & 0.5847\end{array}$


Table 8. Differences of Least Squares Means for Treatments

\begin{tabular}{|c|c|c|c|c|c|c|c|}
\hline Effect & trt & $-\mathrm{trt}$ & $\begin{array}{l}\text { Standard } \\
\text { Estimate }\end{array}$ & $\begin{array}{l}\text { Chi- } \\
\text { Error }\end{array}$ & DF & Square & $\mathrm{Pr}>\mathrm{ChiSq}$ \\
\hline $\operatorname{trt}$ & 1 & 17 & $-\odot .1199$ & 0.6630 & 1 & 0.03 & $\odot .8565$ \\
\hline trt & 1 & 18 & -0.4523 & 0.5935 & 1 & 0.58 & 0.4460 \\
\hline trt & 1 & 19 & 0.4310 & 0.7732 & 1 & 0.31 & 0.5772 \\
\hline $\operatorname{trt}$ & 1 & 20 & -0.5645 & 0.6211 & 1 & 0.83 & 0.3634 \\
\hline trt & 2 & 17 & -0.2483 & 0.6214 & 1 & 0.16 & 0.6894 \\
\hline trt & 2 & 18 & $-\odot .5808$ & $\odot .6440$ & 1 & 0.81 & 0.3672 \\
\hline $\operatorname{trt}$ & 2 & 19 & 0.3026 & 0.7655 & 1 & 0.16 & 0.6926 \\
\hline $\operatorname{trt}$ & 2 & 20 & -0.6929 & $\odot .5682$ & 1 & 1.49 & 0.2226 \\
\hline $\operatorname{trt}$ & 3 & 17 & -0.1203 & 0.6635 & 1 & 0.03 & 0.8562 \\
\hline $\operatorname{trt}$ & 3 & 18 & -0.4527 & 0.5936 & 1 & 0.58 & 0.4457 \\
\hline trt & 3 & 19 & $\odot .4306$ & 0.7738 & 1 & 0.31 & 0.5779 \\
\hline $\operatorname{trt}$ & 3 & 20 & -0.5649 & 0.6223 & 1 & 0.82 & 0.3640 \\
\hline trt & 4 & 17 & $-\odot .6375$ & $\odot .7012$ & 1 & 0.83 & 0.3632 \\
\hline $\operatorname{trt}$ & 4 & 18 & -0.9700 & 0.6869 & $\overline{1}$ & 1.99 & 0.1579 \\
\hline trt & 4 & 19 & $-\odot . \odot 866$ & $\odot .8054$ & 1 & 0.01 & $\odot .9143$ \\
\hline $\operatorname{trt}$ & 4 & 20 & -1.0821 & 0.6597 & 1 & 2.69 & 0.1009 \\
\hline trt & 5 & 17 & 0.1996 & $\odot .5521$ & 1 & 0.13 & $\odot .7178$ \\
\hline trt & 5 & 18 & $-\odot .1329$ & $\odot .5747$ & 1 & 0.05 & 0.8172 \\
\hline trt & 5 & 19 & $\odot .7505$ & 0.7133 & 1 & 1.11 & 0.2927 \\
\hline trt & 5 & 20 & -0.2450 & 0.5004 & 1 & 0.24 & 0.6244 \\
\hline trt & 6 & 17 & $-\odot .6393$ & $0.7 \odot 22$ & 1 & 0.83 & 0.3626 \\
\hline trt & 6 & 18 & -0.9717 & 0.6870 & 1 & 2.00 & 0.1572 \\
\hline trt & 6 & 19 & $-\odot .0884$ & $\odot .8074$ & 1 & 0.01 & $\odot .9128$ \\
\hline $\operatorname{trt}$ & 6 & 20 & -1.0839 & 0.6637 & 1 & 2.67 & 0.1024 \\
\hline trt & 7 & 17 & -0.4065 & 0.6472 & 1 & 0.39 & $\odot .5299$ \\
\hline trt & 7 & 18 & -0.7389 & $\odot .6667$ & 1 & 1.23 & $\odot .2677$ \\
\hline $\operatorname{trt}$ & 7 & 19 & 0.1444 & $\odot .7892$ & 1 & 0.03 & $\odot .8548$ \\
\hline $\operatorname{trt}$ & 7 & 20 & -0.8511 & 0.6036 & 1 & 1.99 & 0.1585 \\
\hline trt & 8 & 17 & $-\odot .2485$ & 0.6211 & 1 & 0.16 & 0.6891 \\
\hline trt & 8 & 18 & -0.5809 & 0.6438 & 1 & 0.81 & 0.3669 \\
\hline trt & 8 & 19 & $\odot .3024$ & $\odot .7655$ & 1 & 0.16 & 0.6928 \\
\hline $\operatorname{trt}$ & 8 & 20 & -0.6931 & 0.5682 & 1 & 1.49 & 0.2225 \\
\hline trt & 9 & 17 & $-\odot .4562$ & $\odot .7250$ & 1 & 0.40 & $\odot .5292$ \\
\hline trt & 9 & 18 & -0.7886 & $\odot .6620$ & 1 & 1.42 & $\odot .2336$ \\
\hline $\operatorname{trt}$ & 9 & 19 & 0.0947 & 0.8268 & 1 & 0.01 & 0.9088 \\
\hline trt & 9 & 20 & -0.9008 & 0.6866 & 1 & 1.72 & 0.1895 \\
\hline trt & 10 & 17 & $-\odot .3033$ & $\odot .6385$ & 1 & 0.23 & $\odot .6348$ \\
\hline trt & 10 & 18 & $-\odot .6357$ & 0.6215 & 1 & 1.05 & 0.3064 \\
\hline trt & 10 & 19 & $\odot .2476$ & $\odot .7530$ & 1 & 0.11 & 0.7423 \\
\hline $\operatorname{trt}$ & 10 & 20 & -0.7479 & 0.5968 & 1 & 1.57 & 0.2101 \\
\hline trt & 11 & 17 & -0.4576 & 0.6663 & 1 & 0.47 & 0.4922 \\
\hline trt & 11 & 18 & $-\odot .7901$ & 0.6499 & 1 & 1.48 & 0.2241 \\
\hline trt & 11 & 19 & $\odot .0933$ & $\odot .7768$ & 1 & 0.01 & $\odot .9044$ \\
\hline trt & 11 & 20 & $-\odot .9022$ & $\odot .6267$ & 1 & 2.07 & 0.1500 \\
\hline
\end{tabular}




$\begin{array}{lllrllll}\operatorname{trt} & 12 & 17 & -0.0478 & 0.5991 & 1 & 0.01 & 0.9363 \\ \operatorname{trt} & 12 & 18 & -0.3803 & 0.5836 & 1 & 0.42 & 0.5147 \\ \operatorname{trt} & 12 & 19 & 0.5031 & 0.7169 & 1 & 0.49 & 0.4829 \\ \operatorname{trt} & 12 & 20 & -0.4924 & 0.5463 & 1 & 0.81 & 0.3673 \\ & & & & & & & \\ \operatorname{trt} & 13 & 17 & -0.0959 & 0.6827 & 1 & 0.02 & 0.8882 \\ \operatorname{trt} & 13 & 18 & -0.4284 & 0.6706 & 1 & 0.41 & 0.5229 \\ \operatorname{trt} & 13 & 19 & 0.4550 & 0.5963 & 1 & 0.58 & 0.4455 \\ \operatorname{trt} & 13 & 20 & -0.5405 & 0.6326 & 1 & 0.73 & 0.3928\end{array}$


Table 8. (Continued). Difference between control and treatments Differences of Least Squares Means

$\begin{array}{lccccccc}\text { Effect } & \text { trt } & \text { trt } & \begin{array}{c}\text { Standard } \\ \text { Estimate }\end{array} & \text { Error } & \text { DF } & \begin{array}{c}\text { Chi- } \\ \text { Square }\end{array} & \text { Pr }>\text { ChiSq } \\ \text { trt } & 14 & 17 & -0.4546 & 0.6644 & 1 & 0.47 & 0.4938 \\ \operatorname{trt} & 14 & 18 & -0.7871 & 0.6497 & 1 & 1.47 & 0.2257 \\ \operatorname{trt} & 14 & 19 & 0.0963 & 0.7732 & 1 & 0.02 & 0.9009 \\ \operatorname{trt} & 14 & 20 & -0.8992 & 0.6195 & 1 & 2.11 & 0.1467 \\ & & & & & & & \\ \operatorname{trt} & 15 & 17 & -0.5862 & 0.6853 & 1 & 0.73 & 0.3923 \\ \operatorname{trt} & 15 & 18 & -0.9186 & 0.7050 & 1 & 1.70 & 0.1926 \\ \operatorname{trt} & 15 & 19 & -0.0353 & 0.8190 & 1 & 0.00 & 0.9656 \\ \operatorname{trt} & 15 & 20 & -1.0308 & 0.6399 & 1 & 2.60 & 0.1072 \\ & & & & & & & \\ \operatorname{trt} & 16 & 17 & -0.4535 & 0.6651 & 1 & 0.46 & 0.4954 \\ \operatorname{trt} & 16 & 18 & -0.7859 & 0.6511 & 1 & 1.46 & 0.2274 \\ \operatorname{trt} & 16 & 19 & 0.0974 & 0.7730 & 1 & 0.02 & 0.8997 \\ \operatorname{trt} & 16 & 20 & -0.8981 & 0.6182 & 1 & 2.11 & 0.1463\end{array}$


Table 9

Reflectors Treatments versus Controls

The GENMOD Procedure

Model Information

$\begin{array}{lr}\text { Data Set } & \text { WORK. NEW } \\ \text { Distribution } & \text { Poisson } \\ \text { Link Function } & \text { Log } \\ \text { Dependent Variable } & \text { y } \\ \text { Observations Used } & 1120\end{array}$

Class Level Information

\begin{tabular}{|c|c|c|}
\hline Class & Levels & Values \\
\hline rep & 2 & 12 \\
\hline Group & 5 & $\begin{array}{lllll}1 & 17 & 18 & 19 & 20\end{array}$ \\
\hline trt & 20 & $\begin{array}{lllllllllllllllllllll}1 & 2 & 3 & 4 & 5 & 6 & 7 & 8 & 9 & 10 & 11 & 12 & 13 & 14 & 15 & 16 & 17 & 18 & 19 & 20\end{array}$ \\
\hline month & 28 & $\begin{array}{lllllllllllllllll}5 & 6 & 10 & 11 & 17 & 18 & 22 & 23 & 29 & 30 & 34 & 35 & 41 & 42 & 46 & 47 & 53 \\
54 & 58 & 59 & 65 & 66 & 70 & 71 & 77 & 78 & 82 & 83 & & & & & & \end{array}$ \\
\hline Rate & 4 & 1245 \\
\hline
\end{tabular}

Criteria For Assessing Goodness of Fit

$\begin{array}{lrrr}\text { Criterion } & \text { DF } & \text { Value } & \text { Value/DF } \\ & & & \\ \text { Deviance } & 1086 & 1293.3039 & 1.1909 \\ \text { Scaled Deviance } & 1086 & 1145.0980 & 1.0544 \\ \text { Pearson Chi-Square } & 1086 & 1226.5570 & 1.1294 \\ \text { Scaled Pearson X2 } & 1086 & 1086.0000 & 1.0000 \\ \text { Log Likelihood } & & -924.1429 & \end{array}$

Algorithm converged.

The GENMOD Procedure

LR Statistics For Type 3 Analysis

\begin{tabular}{lrrrrrr} 
Source & Num DF & Den DF & F Value & Pr $>$ F & $\begin{array}{r}\text { Chi- } \\
\text { Square }\end{array}$ & Pr > ChiSq \\
rep & 1 & 1086 & 0.24 & 0.6233 & 0.24 & 0.6232 \\
X & 1 & 1086 & 2.62 & 0.1056 & 2.62 & 0.1053 \\
month & 27 & 1086 & 3.74 & $<.0001$ & 101.00 & $<.0001$ \\
Group & 4 & 1086 & 2.23 & 0.0636 & 8.93 & 0.0629 \\
\multicolumn{5}{c}{ Differences of Least Squares Means }
\end{tabular}

$\begin{array}{lllrrrrr}\text { Effect } & \text { Group } & \text { _Group } & \text { Estimate } & \begin{array}{r}\text { Standard } \\ \text { Error }\end{array} & \text { DF } & \begin{array}{r}\text { Chi- } \\ \text { Square }\end{array} & \text { Pr }>\text { ChiSq } \\ \text { Group } & 1 & 17 & -0.2121 & 0.1455 & 1 & 2.12 & 0.1450 \\ \text { Group } & 1 & 18 & -0.1273 & 0.1510 & 1 & 0.71 & 0.3992 \\ \text { Group } & 1 & 19 & -0.0707 & 0.1560 & 1 & 0.21 & 0.6504 \\ \text { Group } & 1 & 20 & -0.3775 & 0.1362 & 1 & 7.69 & 0.0056\end{array}$




$\begin{array}{llllllll}\text { Group } & 17 & 18 & 0.0848 & 0.2021 & 1 & 0.18 & 0.6748 \\ \text { Group } & 17 & 19 & 0.1414 & 0.2064 & 1 & 0.47 & 0.4933 \\ \text { Group } & 17 & 20 & -0.1654 & 0.1913 & 1 & 0.75 & 0.3874 \\ \text { Group } & 18 & 19 & 0.0566 & 0.2103 & 1 & 0.07 & 0.7878 \\ \text { Group } & 18 & 20 & -0.2502 & 0.1955 & 1 & 1.64 & 0.2007 \\ \text { Group } & 19 & 20 & -0.3068 & 0.1999 & 1 & 2.36 & 0.1248\end{array}$


Table 10.

Comparisons of all reflector treatments to all controls

The GENMOD Procedure

Model Information

$\begin{array}{lr}\text { Data Set } & \text { WORK. NEW } \\ \text { Distribution } & \text { Poisson } \\ \text { Link Function } & \text { Log } \\ \text { Dependent Variable } & \text { y } \\ \text { Observations Used } & 1120\end{array}$

Class Level Information

\begin{tabular}{|c|c|c|}
\hline Class & Levels & Values \\
\hline rep & 2 & 12 \\
\hline Group & 5 & $\begin{array}{lllll}1 & 17 & 18 & 19 & 20\end{array}$ \\
\hline trt & 20 & $\begin{array}{llllllllllllllllllll}1 & 2 & 3 & 4 & 5 & 6 & 7 & 8 & 9 & 10 & 11 & 12 & 13 & 14 & 15 & 16 & 17 & 18 & 19 & 20\end{array}$ \\
\hline month & 28 & $\begin{array}{lllllllllllllllll}5 & 6 & 10 & 11 & 17 & 18 & 22 & 23 & 29 & 30 & 34 & 35 & 41 & 42 & 46 & 47 & 53 \\
54 & 58 & 59 & 65 & 66 & 70 & 71 & 77 & 78 & 82 & 83 & & & & & & \end{array}$ \\
\hline Rate & 4 & 1245 \\
\hline COM & 2 & 12 \\
\hline
\end{tabular}

Criteria For Assessing Goodness of Fit

$\begin{array}{lrrr}\text { Criterion } & \text { DF } & \text { Value } & \text { Value/DF } \\ \text { Deviance } & 1089 & 1219.8156 & 1.1201 \\ \text { Scaled Deviance } & 1089 & 1219.8156 & 1.1201 \\ \text { Pearson Chi-Square } & 1089 & 1151.5025 & 1.0574 \\ \text { Scaled Pearson X2 } & 1089 & 1151.5025 & 1.0574 \\ \text { Log Likelihood } & & -1043.9348 & \end{array}$

Algorithm converged.

LR Statistics For Type 1 Analysis

$\begin{array}{lrrrr}\text { Source } & \begin{array}{r}2^{*} \log \\ \text { Likelihood }\end{array} & \text { DF } & \begin{array}{r}\text { Chi- } \\ \text { Square }\end{array} & \text { Pr > ChiSq } \\ \text { Intercept } & -2205.3169 & & & \\ \text { rep } & -2205.2755 & 1 & 0.04 & 0.8386 \\ \text { X } & -2195.7091 & 1 & 9.57 & 0.0020 \\ \text { month } & -2094.4008 & 27 & 101.31 & <.0001 \\ \text { COM } & -2087.8696 & 1 & 6.53 & 0.0106\end{array}$

LR Statistics For Type 3 Analysis

$\begin{array}{lrrr}\text { Source } & \text { DF } & \begin{array}{r}\text { Chi- } \\ \text { Square }\end{array} & \operatorname{Pr}>\text { Chisq } \\ \text { rep } & 1 & 0.21 & 0.6503 \\ \text { X } & 1 & 2.77 & 0.0959\end{array}$




\begin{tabular}{|c|c|c|c|c|c|c|c|}
\hline & & $\begin{array}{l}\text { month } \\
\text { COM }\end{array}$ & & $\begin{array}{r}102.29 \\
6.53\end{array}$ & & $\begin{array}{l}\odot \odot \bullet 1 \\
\bullet 106\end{array}$ & \\
\hline & & & ferences & Least Squa & Mear & & \\
\hline Effect & COM & _COM & Estimate & $\begin{array}{r}\text { Standard } \\
\text { Error }\end{array}$ & DF & $\begin{array}{r}\text { Chi- } \\
\text { Square }\end{array}$ & $\mathrm{Pr}>\mathrm{ChiSq}$ \\
\hline COM & 1 & 2 & -0.2038 & $\odot .0784$ & 1 & 6.75 & 0.0094 \\
\hline
\end{tabular}


Table 11. 95\% Confidence intervals of the variables

Criteria For Assessing Goodness of Fit

$\begin{array}{lrrr}\text { Criterion } & \text { DF } & \text { Value } & \text { Value/DF } \\ \text { Deviance } & 1089 & 1219.8156 & 1.1201 \\ \text { Scaled Deviance } & 1089 & 1219.8156 & 1.1201 \\ \text { Pearson Chi-Square } & 1089 & 1151.5025 & 1.0574 \\ \text { Scaled Pearson X2 } & 1089 & 1151.5025 & 1.0574 \\ \text { Log Likelihood } & & -1043.9348 & \end{array}$

Algorithm converged.

Analysis of Parameter Estimates

\begin{tabular}{|c|c|c|c|c|c|c|c|c|}
\hline Parameter & & DF & Estimate & $\begin{array}{r}\text { Standard } \\
\text { Error }\end{array}$ & $\begin{array}{c}\text { Wald } \\
\text { Confidence }\end{array}$ & $\begin{array}{l}5 \% \\
\text { Limits }\end{array}$ & $\begin{array}{l}\text { Chi- } \\
\text { Square }\end{array}$ & $\mathrm{Pr}>$ ChiSq \\
\hline Intercept & & 1 & -0.2013 & 0.2063 & -0.6056 & 0.2031 & 0.95 & 0.3292 \\
\hline rep & 1 & 1 & -0.0305 & $\odot .0673$ & -0.1624 & $\odot .1014$ & $\odot .21$ & $\odot .6502$ \\
\hline rep & 2 & 0 & 0.0000 & 0.0000 & $\odot .00 \odot \odot$ & $\odot .0000$ & & \\
\hline$x$ & & 1 & 0.0591 & 0.0350 & -0.0096 & $\odot .1277$ & 2.84 & $\odot .0918$ \\
\hline month & 5 & 1 & -0.0780 & 0.2781 & -0.6231 & 0.4670 & 0.08 & 0.7790 \\
\hline month & 6 & 1 & -0.9427 & 0.3600 & -1.6483 & -0.2371 & 6.86 & 0.0088 \\
\hline month & 10 & 1 & $\odot .2083$ & $\odot .2589$ & $-\odot .2992$ & $\odot .7157$ & 0.65 & 0.4212 \\
\hline month & 11 & 1 & 0.0645 & 0.2620 & -0.4489 & 0.5780 & 0.06 & 0.8055 \\
\hline month & 17 & $\overline{1}$ & $\odot .2726$ & $\odot .2566$ & -0.2303 & $\odot .7756$ & 1.13 & 0.2881 \\
\hline month & 18 & 1 & -0.4496 & 0.3070 & -1.0513 & 0.1521 & 2.14 & 0.1431 \\
\hline month & 22 & $\overline{1}$ & 0.1205 & $\odot .2640$ & -0.3971 & 0.6380 & 0.21 & 0.6482 \\
\hline month & 23 & 1 & $\odot .2852$ & $\odot .2498$ & -0.2043 & 0.7748 & 1.30 & 0.2535 \\
\hline month & 29 & 1 & 0.2188 & 0.2597 & $-0.29 \odot 2$ & 0.7278 & 0.71 & $\odot .3995$ \\
\hline month & 30 & 1 & -0.5068 & 0.3123 & -1.1189 & 0.1053 & 2.63 & 0.1046 \\
\hline month & 34 & 1 & 0.4817 & 0.2452 & 0.0010 & $\odot .9624$ & 3.86 & $\odot .0495$ \\
\hline month & 35 & 1 & 0.6062 & $\odot .2357$ & $\odot .1442$ & 1.0682 & 6.61 & $\odot .0101$ \\
\hline month & 41 & 1 & $\odot .0986$ & $\odot .2667$ & -0.4242 & 0.6214 & 0.14 & 0.7116 \\
\hline month & 42 & 1 & 0.1265 & $\odot .2645$ & -0.3919 & 0.6449 & 0.23 & 0.6324 \\
\hline month & 46 & 1 & -0.7062 & 0.3315 & -1.3559 & -0.0566 & 4.54 & 0.0331 \\
\hline month & 47 & 1 & 0.3812 & $\odot .2452$ & $-\odot .0993$ & $\odot .8618$ & 2.42 & $\odot .1199$ \\
\hline month & 53 & 1 & 0.3538 & 0.2528 & -0.1416 & 0.8493 & 1.96 & 0.1616 \\
\hline month & 54 & $\overline{1}$ & 0.5510 & 0.2430 & 0.0747 & 1.0272 & 5.14 & 0.0234 \\
\hline month & 58 & 1 & $\odot .5056$ & 0.2444 & 0.0265 & 0.9847 & 4.28 & 0.0386 \\
\hline month & 59 & 1 & 0.3829 & 0.2452 & -0.0976 & 0.8634 & 2.44 & 0.1183 \\
\hline month & 65 & $\overline{1}$ & -0.1169 & 0.2808 & -0.6673 & 0.4335 & 0.17 & $\odot .6772$ \\
\hline month & 66 & 1 & -0.1206 & 0.2805 & -0.6704 & 0.4293 & 0.18 & 0.6674 \\
\hline month & 70 & 1 & 0.0541 & 0.2679 & -0.4709 & 0.5792 & 0.04 & 0.8398 \\
\hline month & 71 & 1 & 0.5297 & 0.2387 & 0.0618 & 0.9975 & 4.92 & 0.0265 \\
\hline month & 77 & 1 & 0.3786 & 0.2515 & -0.1144 & 0.8715 & 2.27 & 0.1323 \\
\hline month & 78 & 1 & $\odot .2952$ & 0.2549 & -0.2045 & 0.7949 & 1.34 & 0.2469 \\
\hline month & 82 & 1 & 0.7482 & 0.2348 & 0.2881 & 1.2084 & 10.16 & 0.0014 \\
\hline month & 83 & 0 & 0.0000 & 0.0000 & 0.0000 & 0.0000 & & \\
\hline $\mathrm{COM}$ & 1 & 1 & -0.2038 & $\odot .0784$ & -0.3576 & -0.0501 & 6.75 & $\odot .0094$ \\
\hline $\mathrm{COM}$ & 2 & 0 & 0.0000 & 0.0000 & 0.0000 & 0.0000 & & . \\
\hline Dispersion & & 1 & 0.0799 & 0.0520 & 0.0223 & 0.2863 & & \\
\hline
\end{tabular}


Figure 1. Typical Reflector Installation

Dual shoulder and dual median reflectors (T3 or T7)
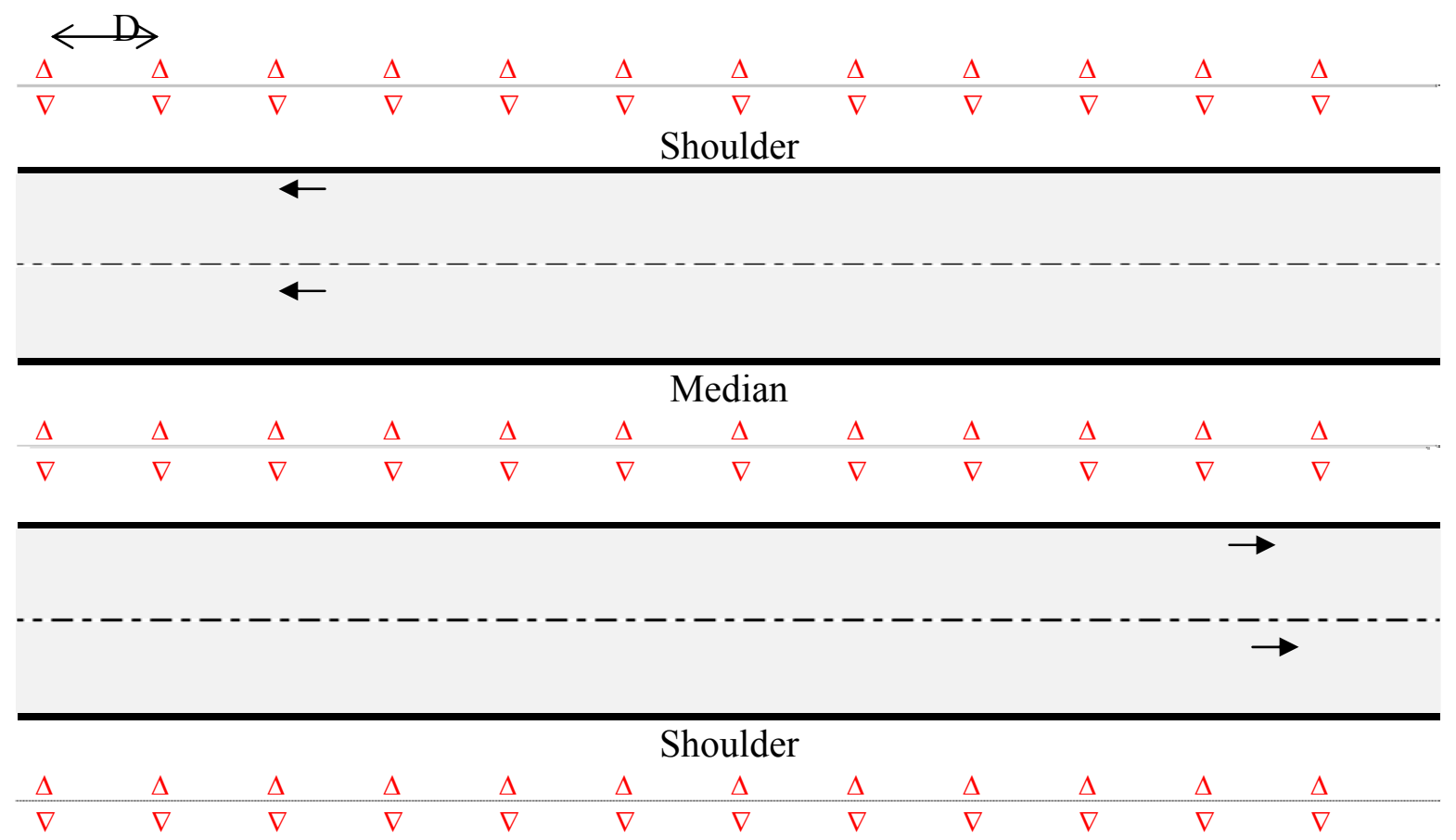

\section{LEGEND:}

Reflector Line

$\Delta \quad$ Reflector

$\mathrm{D}=$ Distance between reflectors; 30 or 45 meters 
Figure 2. Typical Reflector Installation

Dual shoulder and no median reflectors (T4 or T8)

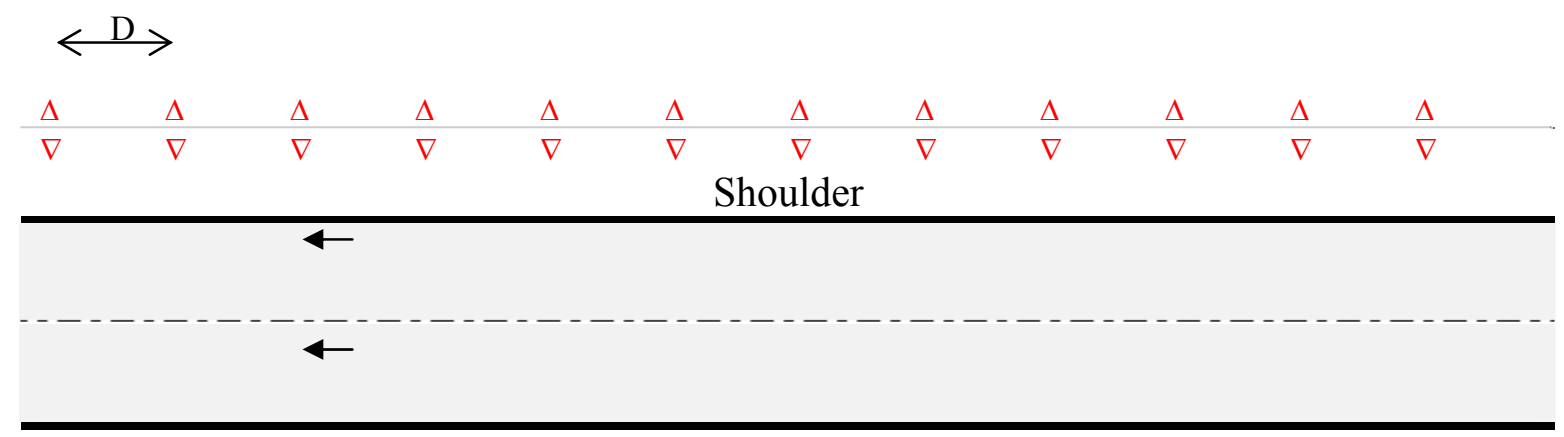

Median

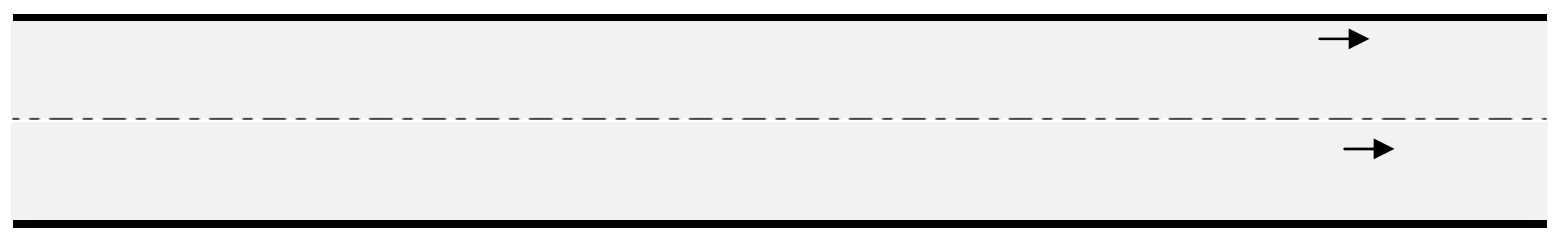

Shoulder

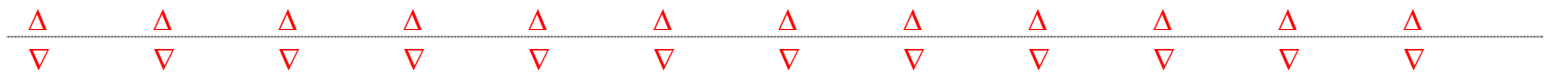


Figure 3. Typical Reflector Installation

Single shoulder and dual median reflectors (T1 or T5)

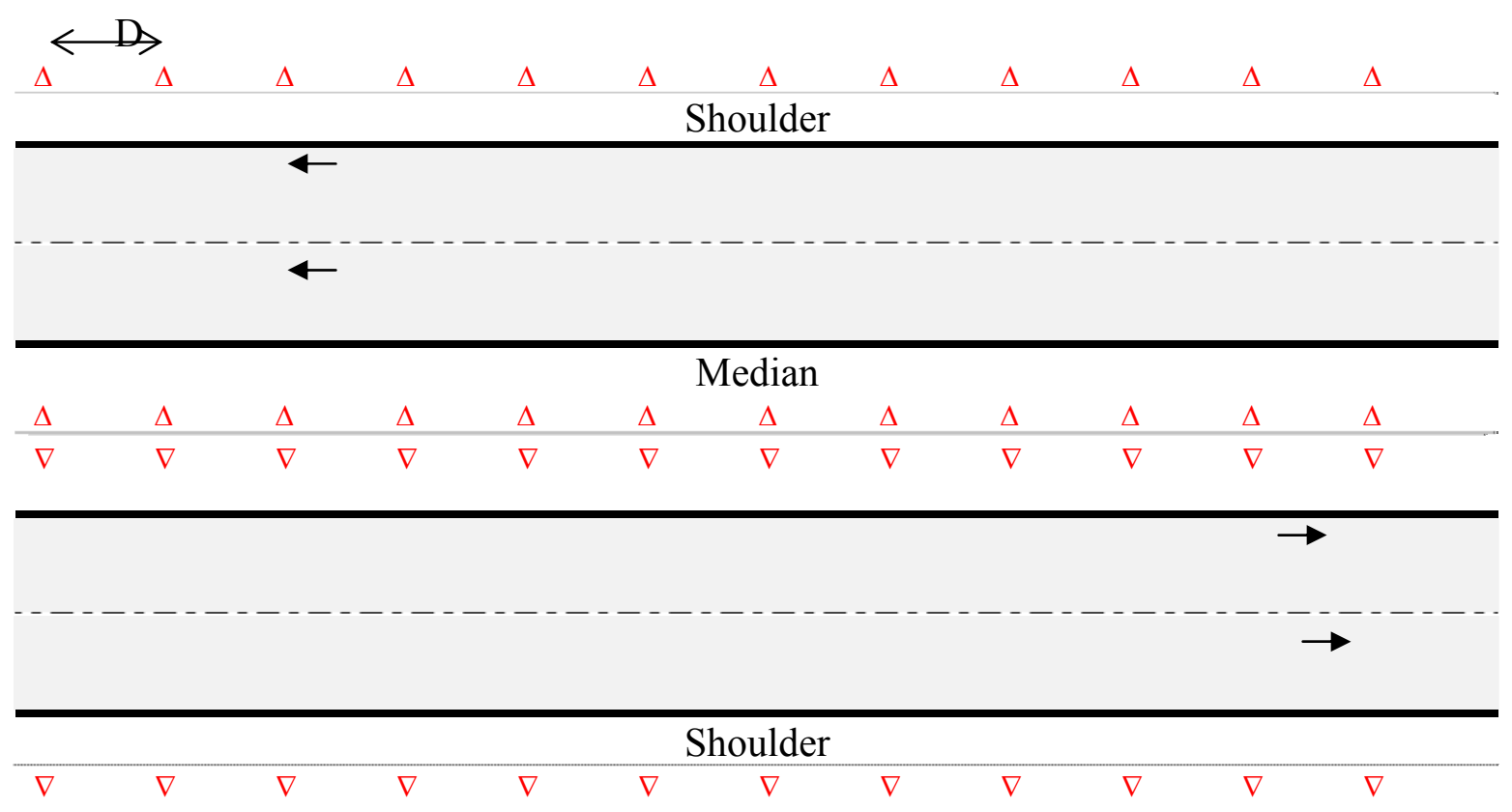


Figure 4. Typical Reflector Installation

Single shoulder and no median reflectors (T2 or T6)

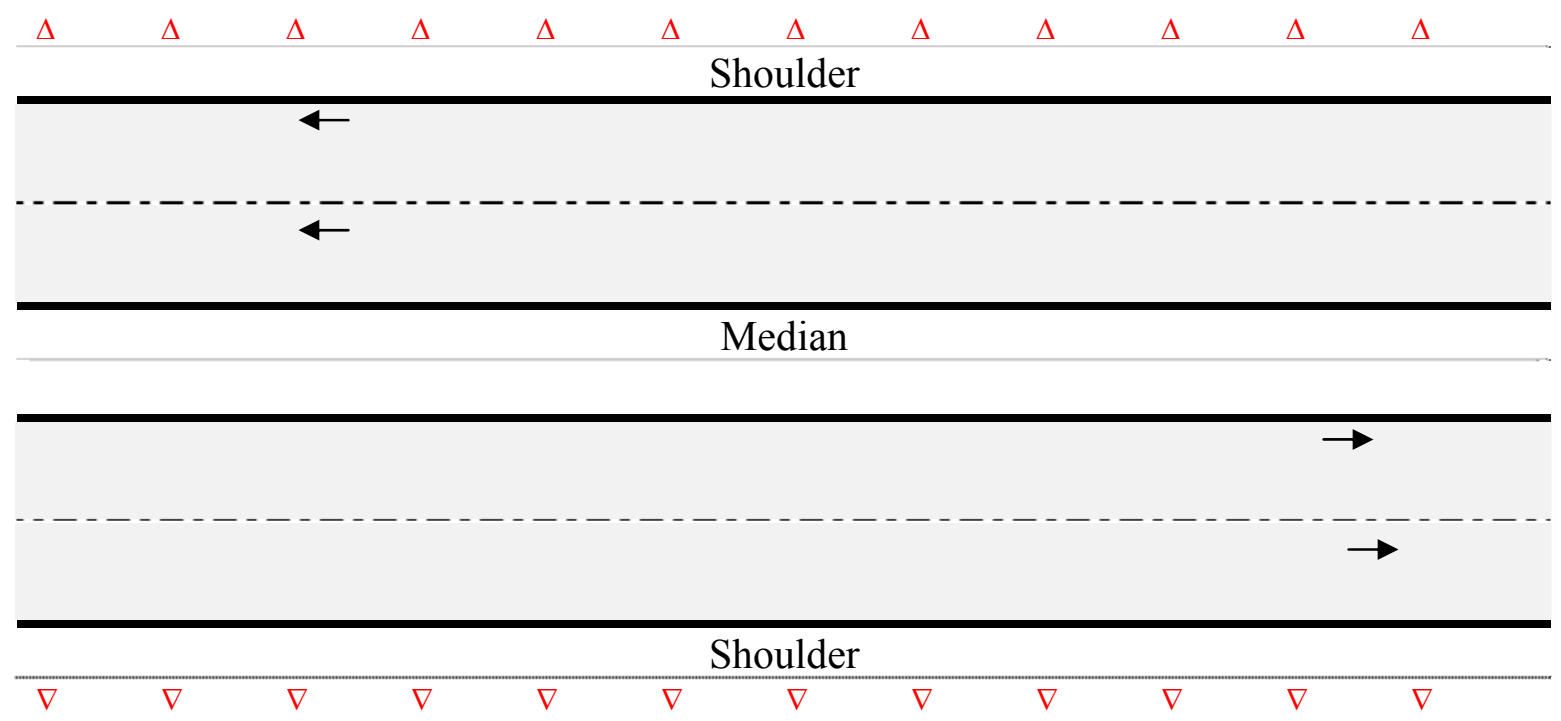


Figure 5. Single and Double Reflectors

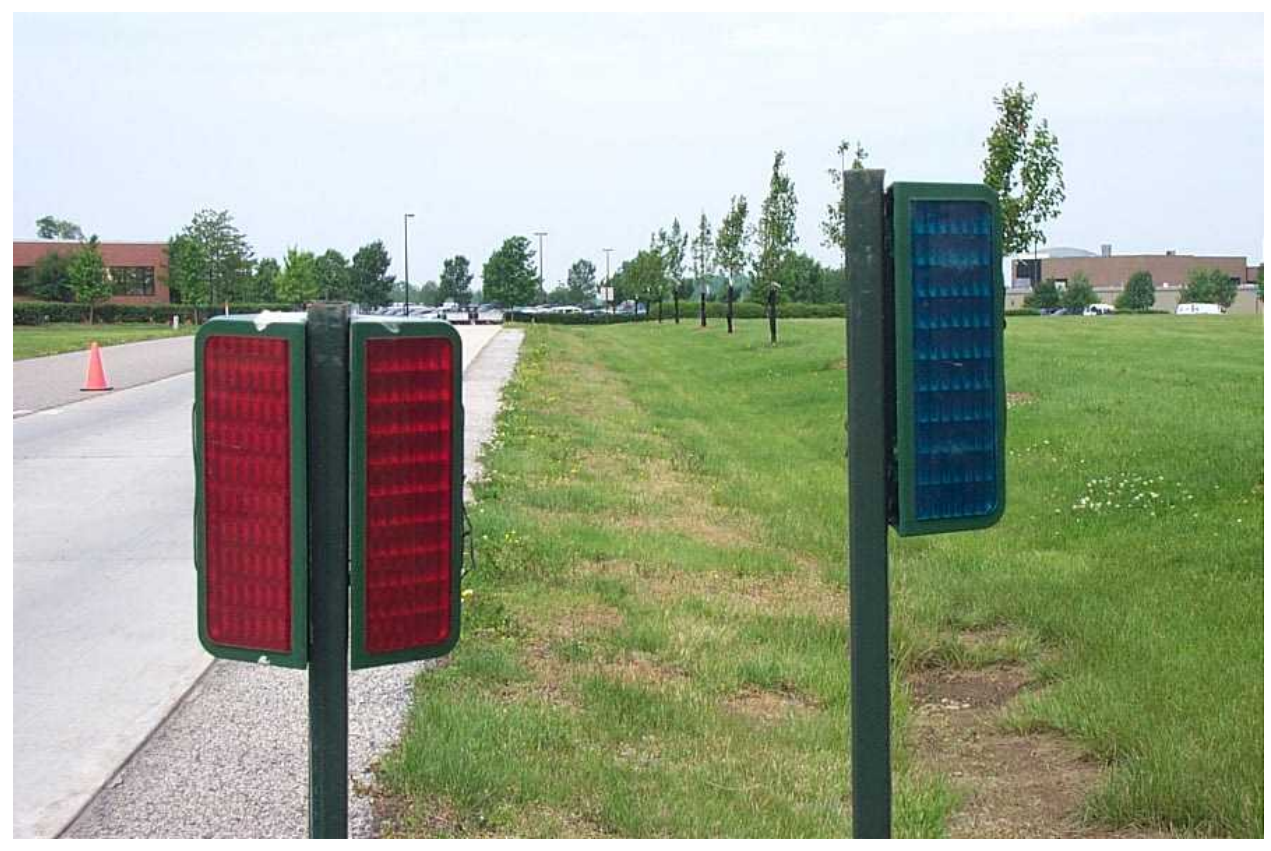


Figure 6. The number of deer-kills along the test sections by months.

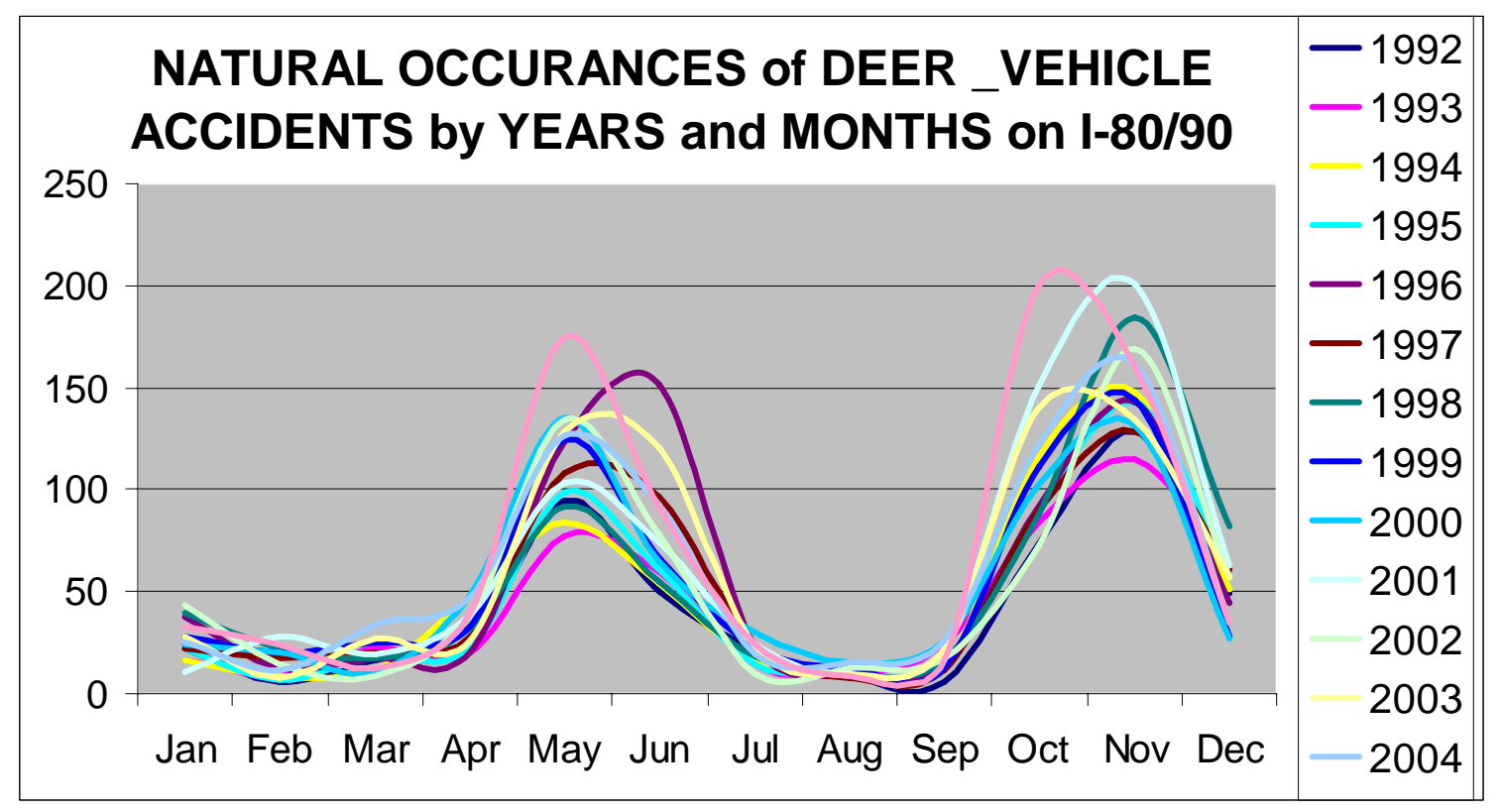




\section{Accumulative Deer Kill Reports on Toll Road}

\begin{tabular}{|c|c|c|c|c|c|c|c|c|c|c|c|c|c|}
\hline Year & J & F & M & A & M & J & J & A & S & O & N & D & Total \\
\hline 1992 & 22 & 6 & 16 & 24 & 95 & 50 & 21 & 9 & 6 & 73 & 128 & 49 & 499 \\
\hline 1993 & 16 & 9 & 22 & 20 & 77 & 60 & 14 & 10 & 24 & 84 & 115 & 62 & 513 \\
\hline 1994 & 16 & 9 & 12 & 47 & 84 & 54 & 16 & 11 & 13 & 116 & 148 & 51 & 577 \\
\hline 1995 & 22 & 7 & 18 & 22 & 98 & 61 & 14 & 10 & 14 & 89 & 143 & 61 & 559 \\
\hline 1996 & 38 & 13 & 17 & 20 & 124 & 152 & 23 & 9 & 15 & 92 & 143 & 44 & 690 \\
\hline 1997 & 22 & 17 & 20 & 28 & 108 & 97 & 23 & 8 & 12 & 90 & 128 & 61 & 614 \\
\hline 1998 & 40 & 22 & 17 & 32 & 92 & 55 & 18 & 10 & 16 & 88 & 184 & 82 & 656 \\
\hline 1999 & 28 & 20 & 25 & 33 & 125 & 67 & 22 & 13 & 13 & 111 & 144 & 28 & 629 \\
\hline 2000 & 24 & 20 & 11 & 48 & 135 & 65 & 30 & 15 & 26 & 102 & 131 & 27 & 634 \\
\hline 2001 & 11 & 28 & 19 & 39 & 103 & 74 & 24 & 9 & 22 & 151 & 201 & 63 & 744 \\
\hline 2002 & 43 & 14 & 9 & 39 & 134 & 78 & 10 & 13 & 17 & 72 & 169 & 57 & 655 \\
\hline 2003 & 28 & 8 & 27 & 26 & 128 & 121 & 23 & 10 & 21 & 140 & 134 & 57 & 723 \\
\hline 2004 & 25 & 12 & 34 & 47 & 126 & 93 & 19 & 15 & 26 & 122 & 161 & 35 & 715 \\
\hline 2005 & 33 & 24 & 13 & 40 & 175 & 92 & 24 & 9 & 16 & 200 & 160 & 35 & 821 \\
\hline
\end{tabular}


Figure 7. The number of deer killed along the mile posts for the months April, May, October and November.

\section{DEER_VEHICLE COLLISIONS}

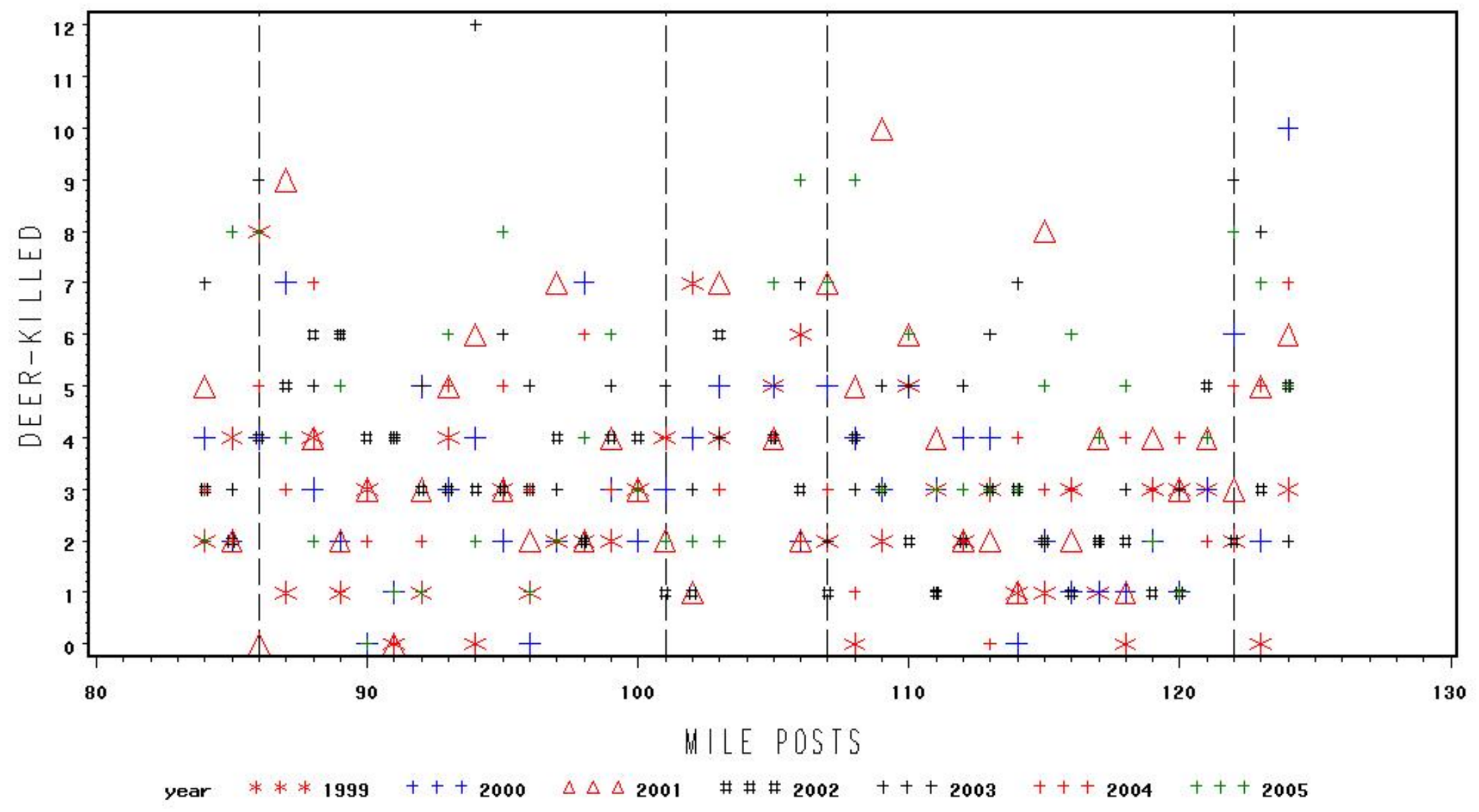

